\title{
Wallets, Ballots, or Bullets: Does Wealth, Democracy, or Military Capabilities Determine War Outcomes? ${ }^{1}$
}

\author{
Errol A. Henderson \\ Pennsylvania State University \\ AND \\ Reşat BAYER \\ Koç University
}

\begin{abstract}
We examine the extent to which wealth, democracy, and/or relative military capabilities contribute to victory in interstate war. Examining contingency tables, we find that states with greater military capabilities are more likely to win their wars whether they are wealthier or democratic, and democratic states perform marginally better than wealthier states in war. Probit analyses indicate that although each of the variables has a robust and positive impact on war victory, relative capabilities has the strongest substantive impact, followed by wealth, then democracy. Hazard analyses reveal that states with greater military capabilities fight shorter wars than either democracies or wealthier states, and controlling for capabilities and wealth, the relationship between democracy and war duration is not significant, which challenges the view that democracies have a unique propensity to fight shorter wars. We also find that the democratic victory phenomenon is not universal, but is contingent on the placement of a single country, Israel, in the Western or non-Western democracy category. In sum, our analyses indicate that although each of the three factors contributes to war victory, relative military capability is the most powerful, consistent, and robust predictor to victory in interstate war.
\end{abstract}

Prominent theses on the determinants of victory in interstate war often emphasized factors associated with power, usually considered in terms of the relative military capabilities of states. Nevertheless, early systematic research on war outcomes supported the view that wealthier states were more likely to win their wars (Rosen 1972). More recently, analysts proposed a "democratic victory thesis," which suggests that democracies are more likely to win their wars (Lake 1992; Stam 1996; Reiter and Stam 1998). Interestingly, while earlier research downplayed the role of democracy in determining war outcomes, the latter, in turn, seems to have inadequately addressed the impact of wealth. Subsequently, a rival thesis rooted in the realist tradition emerged as a critique of the democratic victory thesis and insisted that states with greater relative military capabilities are more likely to win their wars regardless of their regime type (Desch 2002). In this study, we attempt to determine the extent to which wealth, democracy, or relative capabilities best accounts for victory in interstate war. The essay proceeds in several sections. First, we provide some brief background of the early systematic literature on war outcomes. Second, we turn to Rosen's (1972) work, which refocused the attention of scholars to the impact of economic factors on war outcomes. Third, we discuss the democratic victory thesis, focusing mainly on the studies of Stam (1996) and Reiter and Stam (1998, 2002), which challenged Rosen's findings and several realist assumptions as well. Fourth, we discuss the realist thesis that emphasizes the role of relative capabilities in

\footnotetext{
'Authors' note: We thank the editors, anonymous reviewers, and J. David Singer, Allan Stam, Michael Desch, and Dan Reiter for their comments. Gizem Sözündeduran, Ezgi Aydın, and Nihan Memişoğlu provided able research assistance. Data can be obtained from either author or from http://home.-
} ku.edu.tr/ rbayer/. war outcomes through an analysis of Desch's (2002) arguments, which challenged democratic victory claims. Fifth, we test the rival claims using three estimation techniques: contingency table analyses, probit regression, and hazard rate analyses of interstate wars from 1816 to 2007. Sixth, we discuss our findings and their implications. Seventh, and finally, we conclude with a summary of the main points of the essay.

\section{Determining War Outcomes: Early Research}

Toward the end of World War II, a consultant to US Secretary of War Henry L. Stimson, William Shockley (who would later win the Nobel Prize for the development of transistors), suggested that a historical survey of casualties might help the Allies determine under what conditions Japan might surrender (Singer and Small 1972). ${ }^{2}$ At the urging of Quincy Wright, one of his associates in his Study of War project, Frank Klingberg, undertook such a study, but it was not completed in time to influence strategic planning during the war. Having seemingly lost its relevance, the study remained unpublished, but the author was eventually persuaded to publish it in abbreviated form in 1966. In the interim, research on the extent to which the casualties and costs of wars compelled belligerents to surrender was largely anecdotal and speculative (Calahan 1944; Kecskemeti 1958; Coffey 1965). An exception was Richardson's (1960:299) systematic work, which failed to uncover a general pattern of casualty ratios for defeated regimes among the cases of "deadly quarrels" from 1820 to 1945. Since Richardson's work was obscure among political scientists, Klingberg's study served as the

\footnotetext{
${ }^{2}$ Schokley also became a prominent eugenicist.
}

Henderson, Errol A. and Ręsat Bayer. (2013) Wallets, Ballots, or Bullets: Does Wealth, Democracy, or Military Capabilities Determine War Outcomes? International Studies Quarterly, doi: 10.1111 isqu. 12026

(C) 2013 International Studies Association 
point of departure for many of the subsequent systematic analyses of war outcomes in International Relations. Klingberg, like Richardson, did not uncover strong relationships between casualties and capitulation in war. While he found that "in most cases, the casualty percentages for the defeated nations were considerably higher" than those of the victorious states, he found "no constant ratio" for casualties of defeated states (Klingberg 1966:141). Klingberg's analysis was limited because "total military and civilian losses attributable to war could be determined for only eight major wars during the entire period" of 1618-1918 (Klingberg 1966:133).

Progress on the systematic analysis of the determinants of war outcomes advanced considerably with the publication of the Correlates of War (COW) project data in 1972. With the United States facing military defeat in Vietnam, scholarly interest was piqued by the fact that while US forces had not lost a major military engagement in the war, North Vietnam seemed no closer to conceding defeat. Two studies published in that year systematically examined when belligerents were likely to concede defeat in war. First, Singer and Small utilized their data on interstate wars from 1816 to 1965 , which included battle deaths for each state participant in war, to examine the conditions under which states were likely to concede defeat in war and found "no particular threshold at which either the ultimate victors or the ultimate losers...bring hostilities to a close" and concluded that "there is not any absolute or relative battle death threshold at which nations withdraw, or at which wars come to an end" (Singer and Small 1972:371). Second, Rosen (1972) examined the extent to which demographic and economic factors influenced war outcomes; specifically, he was concerned with whether states that suffered fewer battle deaths and/or those with more wealth were less likely to lose wars than those with the opposite characteristics. In an analysis of wars from 1816 to 1945, he found that a narrow majority $(22 / 40$ cases, or $55 \%)$ of those who suffered fewer battle deaths won their wars, and in $75 \%$ of the wars $(30 / 40$ cases $)$, the winning side lost a lower percentage of its troops. Rosen's "principal finding" was that the side that was wealthier won almost $80 \%$ $(31 / 39)$ of the wars.

The centrality of wealth in war outcomes was supported by Wayman, Singer, and Goertz (1983), who found that industrial capacity rather than military capability or population was a more important determinant of victory for states initiating wars, and in an indirect sense by Organski and Kugler's (1978) findings that in many cases where apparently militarily weaker states prevailed in war (for example, the Vietnam War), they had been able to extract resources from their societies at a much greater rate than their adversaries, which increased their warfighting capacity. Importantly, Rosen (1972:259), prefiguring Organski and Kugler (1980), did not view wealth as just an indirect contributor to military power but as "the most useful simple measure of physical strength in warfare." In fact, his findings implied that it was difficult to overcome an adversary's economic and demographic advantages by military strategy, leadership, or fighting prowess; however, Rosen's study ignored political factors such as regime type, and some scholars addressed this omission by promulgating the "democratic victory thesis," which suggests that democracies are more likely to win wars.

Theses that attempted to explain why democracies are more likely to win their wars fall into two general catego- ries: "war selection" and "war fighting." The former focuses on the presumably greater capacity of democracies to select wars that they can win, and the latter focuses on the presumably greater capacity of democracies to win the wars that they select (or have imposed on them). For example, a prominent "war selection" thesis argues that since democratic leaders must stand for regular elections, they are constrained in their foreign policy choices out of fear of defeat at the polls if they lose wars; therefore, they select "winnable wars" that target weaker states, are of shorter duration, and incur fewer casualties (Reiter and Stam 2002). A related argument is that the marketplace of ideas tends to generate high-quality information on which democratic leaders and their attentive publics can base their decisions for war, unlike in nondemocratic systems characterized by restrictions on the flow and critical assessment of information, the repression of dissenting opinions, and the monopolizing of the decision-making process by autocratic leaders (Reiter and Stam 2002). The prominent "war fighting" thesis maintains that democratic political culture generates better leadership and initiative among troops, making them more effective fighters (Reiter and Stam 2002). A variant suggests that democracies tend to employ more effective strategies in war than nondemocracies (Reiter and Meek 1999) or that democracies are more likely to ally with each other, to cooperate more effectively, and as a result defeat nondemocratic adversaries (Choi 2003, 2004). Another version insists that since democratic publics share in the gains of victory and the losses of defeats, they provide greater public support for war and, subsequently, are more willing to sacrifice for the war effort as compared to autocratic publics. Other war-fighting arguments claim that given their willingness to shift a greater share of resources to the war effort (Bueno de Mesquita, Smith, Siverson, and Morrow 2004), and/or their lower propensity for rent seeking as compared to autocratic states (Lake 1992), democracies are able to mobilize a greater share of their wealth for war.

Lake (1992) provided the initial empirical substantiation of the democratic victory thesis, which he argued reflected the greater ability of democracies to generate wealth given their assumed lower propensity for rent seeking as compared to autocratic states. Although Lake's argument suggested the importance of wealth in democratic victory, he found no significant relationship between the two. Moreover, Lake's study focused exclusively on wars in which a democratic state participated and included only 26 wars and 121 observations, as compared to the 40 wars analyzed in Rosen's (1972) study published 20 years previously. Stam (1996:177) corroborated Lake's finding that democracies are more likely to win their wars, which he speculated might result from either greater legitimacy, the greater likelihood of democratic publics to share in the gains of victory and the losses of defeats, or the tendency of democratic leaders to select "winnable" wars (that is, "war selection"). For Stam, factors associated with the ability of states to directly affect the military situation on the ground (that is, strategy and balance of forces) are the primary determinants of war outcomes. He found that controlling for the doctrine (that is, offensive, defensive) and strategy (that is, maneuver, attrition, and punishment) of belligerents in war, the demographic factors that Rosen focused on had little impact on war outcomes (170). Stam laid the basis for later research that linked democratic victory in war to the propensity of democracies to employ certain 
types of strategy. Since Stam (1996:21-22) focused on factors that can be determined ex ante, he did not include battle deaths in his analyses. Moreover, while he controlled for relative capability, which is a composite that includes the industrial capability of states, he did not control for wealth, specifically, which is the variable on which Rosen's "principal finding" rests.

Reiter and Stam (1998) expanded on this work and provided empirical support for both the war-fighting and war-selection arguments. Reiter and Meek (1999) found that democracies select more effective war-fighting strategies-namely, maneuver strategies-than nondemocracies, which Reiter and Stam (2002:38) view as supporting their war-selection argument: They note that "democracies seek wars that are short, successful, and with low casualties, all of which are virtues promised by maneuver strategies." They also found that democracies are not more likely to win their wars because democratic allies come to their aid (Reiter and Stam 2002:108113). ${ }^{3}$ They not only confirmed the war-selection variant of the democratic victory thesis, but they also examined the impact of wealth on democracy and found "no statistically significant relationship between a state's political institutions and the size of its economy" and also that "democratic belligerents did not enjoy larger economies or greater industrial production than did nondemocratic belligerents" (Reiter and Stam 2002:117). They concluded that "democracies that have fought wars over the last two centuries have not won their wars because they had systematically larger economies than their opponents did" (117). Their conclusions supported the democratic victory thesis and gainsaid Rosen's argument on the centrality of wealth in war outcomes; however, their findings rest mainly on regressions of economic capacity on democracy and war initiation, instead of analyses of the impact of wealth on interstate war outcomes, specifically.

Although various studies have supported the democratic victory thesis, it is not without its detractors; among the most prominent are those that endorse the longstanding realist view that it is power-operationalized as relative military capabilities-more than democracy that determines war outcomes. For example, Desch (2002:16) critiques the democratic victory thesis based in large part on such realist claims. He also argues that Reiter and Stam's (2002) findings rest on several miscodings and misaggregations of war data, errors of historical interpretation, and case selection that is logically inconsistent with the underlying theoretical argument-including several codings of war outcomes involving democracies (for example, the Vietnam War, the War of Attrition, and the Lebanon War). He also critiques Reiter and Stam's claim that troops of democracies perform better in battle, which they attribute to democratic political culture, which presumably fosters individual initiative and better leadership. However, Desch argues that the CHASE and HERO data that the authors draw on for their measures of initiative and leadership are unreliable, with error rates in the data from $5 \%$ to $30 \%$. Among the misaggregations, Desch argues that World War II, which is treated as a case of democratic victory, should be disaggregated into three distinct conflicts, with victory ensuing largely from the

\footnotetext{
${ }^{3}$ This result contradicts Choi's claim that democratic victory results from democratic allies aiding each other since in her findings these relationships are not significant (Choi 2004:676).
}

greater military capabilities of the aligned forces rather than the states' regime type. He argues that "in the spring of 1940, Nazi Germany went to war against Britain, Belgium, France, and the Netherlands," and "[e]arly in the war, the Germans, who were about as powerful...as their democratic adversaries, nonetheless defeated them decisively" (Desch 2002:13). In the ensuing war in Europe, democratic France was defeated, and the subsequent Allied victory owed less to the democracy of their regimes or the superior leadership and initiative of their troops than to the fierce fighting of Soviet troops who were "principally responsible for defeating Nazi Germany" (Desch 2002:14). According to Desch, the democratic victory thesis "overstates the effectiveness of the democracies [in warfare] and misses the real reasons why they were on the winning side" (Desch 2002:13). For him, the Allies' victory was owed to their almost 4 to 1 advantage in iron and steel, an almost 2 to 1 advantage in military manpower and roughly a 2.5 to 1 advantage in population as compared to the Axis Powers. A similar "gross mismatch" was evident in the Pacific Theater, leading Desch to conclude that military capability rather than democracy was responsible for the victory of democracies in World War II. Desch (2008) also argued against the salience of democracy in the Polish victory in the Russo-Polish War, the British victory in the Falklands/Malvinas War, and Israel's victories in its wars from 1948 to 1982.

Desch's main argument that military capabilities more than regime type are responsible for democratic victory in war is actually consistent with earlier claims of Reiter and Stam (1998:387) that "democracy makes, on average, less of a contribution to determining war outcomes than does strategy or military capability." Reiter and Stam (2002:197) report similar results-indicating a convergence between the contrasting theses on this point; however, the authors also assert that democracy is the "surest means" to military success, and subsequently, Desch (2002) and Downes (2009a,b) would argue that the relationship between democracy and war outcomes is neither substantively nor statistically significant.

Specifically, Desch argued that Reiter and Stam's inclusion of "gross mismatches" in their analyses skews their findings, since the democracies in these wars could rely on greater capabilities, the support of nondemocratic allies, and/or asymmetries of interest. He argued that these "unfair fights" did not comport with the logic of the democratic "war-fighting" argument. Removing these "unfair fights" from the data set, he re-analyzed Reiter and Stam's main results and found that the impact of democracy is reduced to nonsignificance. Desch (2002:18) concluded that "the correlation between democracy and military victory is spurious," and his results were supported by Downes (2009a:30) findings that with modest changes in Reiter and Stam's (2002) research design-disaggregating states that join the fighting from targets and including draws-that "no type of belligerent-initiators, targets, or joiners-is significantly more likely to win (or less likely to lose) as it becomes more democratic." Thus, Desch and Downes argue that democracy is not significantly associated with military victory. Reiter and Stam's (2003, 2009)

\footnotetext{
${ }^{4}$ For Stam (1996:134-135, 196-197), the average effect of democracy on war outcomes is small though significant, while its potential effect-though larger-is much less than that of realpolitik factors.
} 
responses to these critics extended the debate, but did not resolve it -as both Desch's (2003) and Downes' (2009b) respective rejoinders demonstrate.

Interestingly, although Downes' findings may be viewed as supporting realist claims, he does not provide a wholesale endorsement of Desch's argument regarding capabilities; instead, he focuses on the role of nonmaterial factors in war victory, concluding that "more research is necessary not only to parse the varied effects of democracy on military effectiveness, but also to investigate alternative factors that may provide superior explanations for military outcomes" (Downes 2009a:13). So Downes' findings may be viewed as endorsing theses that emphasize the positive role of both/either material or nonmaterial factors in war victory. In fact, such a cross-pollination of theses is evident in Desch's assertion of the salience of both capabilities and wealth-and in Reiter and Stam's (1998) claims regarding the salience of both realist factors and democracy. Thus, Desch's arguments not only support his realist thesis, but indirectly Rosen's thesis on wealth and war outcomes too, insofar as Desch notes that it is not democracy as much as the "preconditions" of democracy that "confer military victory" to democratic states (Desch 2002:18), and one of the prominent preconditions of democracy is wealth (Mousseau, Hegre, and Oneal 2003). Desch (2008:171-172) recognizes that "wealth is one of the key sinews of military power," and "[w] ealthy states are much more likely to be democratic." 5 Thus, while Desch (2008:174) insists that "national power" is "the most important powerful and consistent predictor of whether a state will win or lose a war" and that "power play[s] a more important role in explaining victory than does democracy" (Desch 2003:182), he also maintains that wealth more than regime type is responsible for democratic victory in wars. All told, his thesis asserts that capabilities have the greatest impact on victory, followed by wealth, and that both of these as well as "nonmaterial constituents of military effectiveness" play a greater role than democracy in war outcomes.

Desch's and Downes' critique and Reiter and Stam's (2003, 2009) responses highlight two aspects of the democratic victory thesis that are important to distinguish. The first is that democracies-as compared to other regimes-are more likely to win their wars; that is, democracies perform better in war than nondemocracies. The second is that democracy-as compared to other factors -is responsible for victory in interstate war; that is, democracy is a more powerful determinant of victory in war than either wealth or relative capabilities. Reiter and Stam (2002) and Lake (2003) consistently support the first contention, which is the main claim of democratic victory advocates, but they, at times, seem to support the second contention as well. For example, in his initial study, Lake (1992:32) claimed that "military strength, industrial capacity, and the ability to choose to wage war appear to be far less important determinants of victory than governmental form." Similarly, Reiter and Stam (2002:197) argue that "democracy has also been the surest means to power in the arena of battle" (emphasis added). Both of these assertions endorse the view that democracy-as com-

${ }^{5}$ Mearsheimer (2001:82) suggests that wealth is "the foundation of military might.", pared to other factors - is a stronger determinant of victory in interstate war. ${ }^{6}$ Desch and Downes challenge both aspects of the democratic victory thesis and insist that military capabilities, wealth, nonmaterial correlates, and/or preconditions of democracy-more than democracy itself-lead to victory in war. Given these divergent theses, in the next section, we begin our analyses of whether wealth, democracy, or capabilities is more strongly associated with victory.

\section{Determining War Outcomes: Contingency Table Analyses}

Our initial examination utilizes contingency tables, or cross-tabs, to provide simple bivariate presentations of the data, which, nonetheless, allow us to see why there is so much disagreement on the relative impact of each of the key factors-wealth, democracy, and capabilities-on war outcomes, because in straightforward comparisons each of them is clearly associated with war victory. The spatial-temporal domain includes all interstate wars from 1816 to 2007 from the COW project (Sarkees and Wayman 2010). ${ }^{7}$ The unit of analysis is the state participant in one of the 79 wars that have win/lose outcomes, extending Reiter and Stam's 197 observations to 230 by including the Gulf War, Bosnian War, Azeri-Armenian War, Ethiopian-Eritrean War, Kargil War, Kosovo War, Afghanistan War, and the US-Iraq War participants. Following Reiter and Stam, we disaggregate World War I, World War II, and the Vietnam War into several dyads allowing us to avoid problems in previous research where members of the winning side were coded as victors even if they had been defeated individually (39). We rely on three main predictor variables to test our respective theses: gross domestic product (GDP) for the "wealth thesis," regime scores for the democratic victory thesis, and relative military capabilities for the realist thesis. Taking each in turn, wealth is estimated using GDP (in 1990 dollars); however, given the relative scarcity of GDP data for most states prior to World War II, we also utilize the energy consumption variable from COW, which measures the extent of industrialization and proxies economic development, and is similar to Reiter and Stam's (2002:137) approach. ${ }^{8}$ We also construct a variable indicating whether the state was on the wealthier side in the war based on Rosen's

\footnotetext{
6 The characterization of democracy as the "surest means to power" is inconsistent with Reiter and Stam's (2002:138-140, tables 5.1-5.3) empirical findings that democracies do not win their wars because they have greater relative capabilities - a common operationalization for power in analyses of war. They are unambiguous that "among war participants, democracies do not possess significantly greater economic capabilities...they do not have significantly higher scores on the aggregate capability index, nor do they have higher levels of energy consumption or iron and steel production," and "[t]he results do not change if we restrict the analysis to only those states that have won wars"' (Reiter and Stam 2002:138; see also Reiter and Stam 2003:177). In addition, to the extent that Reiter and Stam suggest that an intrinsic quality of democracy - specifically, better leadership, initiative, and unwillingness to surrender on the part of troops of democratic states-accounts for democratic victory in war, and this small advantage is, nonetheless, critical as a determinant of war victory, then one may assume that their allusion to democracy as the "surest means to power in the arena of battle" implies that the intrinsic quality of democracy, at least in the case of warfare involving democracies, is more critical than other factors.

Like Reiter and Stam (2002), we include the Serbo-Bulgarian War of 1885 that is not in COW (Singer and Small 2005), and we exclude the Libyan-Chad War of 1986-1987, which is not in Reiter and Stam (2002).

${ }^{8}$ In a few mostly nineteenth century cases, energy data are unavailable (for example, the First Central American War), and we base our estimates on other dimensions of the CINC score, or the CINC score itself.
} 
(1972) revenue data, which is updated with GDP and energy consumption data. ${ }^{9}$ The democracy variable is the regime score from Polity that ranges from -10 to +10 . States with scores of +6 and above are coded as democratic and those below +6 are coded as not democratic. Finally, our relative military capabilities variable is the CINC score from COW, which is based on the proportional share of a state's aggregate military personnel, military spending, iron and steel production, energy consumption, and urban and total population.

Focusing initially on the relationship between wealth and democracy, Table 1 shows that states that were both wealthier and democratic have won all of their wars (that is, $32 / 32$ or $100 \%$ ), while warring states that were neither wealthier nor democratic have won only $29 \%$ (28/97) of their wars. ${ }^{10}$ Democracies win slightly more $(47 / 55$ or $85 \%)$ of their wars than wealthier states win theirs $(81 / 110$ or $74 \%)$; however, in $68 \%$ of the 47 cases of democratic victory, the democratic state was wealthier than its opponent(s), so in more than half of the cases of democratic victory, success may be attributable to greater wealth. Further, the preponderance of wars won by lesswealthy democracies consist of Israel's wars, whose categorization as victories attributable to democracy is challenged by Desch (2002), who, like Van Creveld, attributes the success of Israeli troops "to the fact that they had no choice but to fight well or risk death," given their view of Nasser as "a second Hitler" or that "another Holocaust" was imminent (41). ${ }^{11}$ When such incentives were not present, he notes that Israel did not fight very effectively, as in its invasion of Lebanon in 1982 and in the Intifada. But even if one were to accept Desch's critique at face value, slightly more than half of the remaining cases in which less wealthy democratic states win their wars do not involve Israel. ${ }^{12}$ The results also show that wealthier nondemocracies have won $63 \%(49 / 78)$ of their wars, which is almost the same success rate of democracies that were not wealthier (that is, $15 / 23$ or $65 \%$ ). Interestingly, in $100 \%$ of the cases of democratic defeat in war (8/8), the democracy was less wealthy than its counterpart. ${ }^{13}$

The head-to-head tests in Table 2 allow us to contrast the relative rate of success when the two theses make opposite predictions. The cases in the middle rows constitute the critical tests. Both greater wealth and democracy are associated with the highest likelihood of victory in war; their absence reduces the likelihood of victory by more than $70 \%$. However, in cases in which the two theses predict different outcomes, the results indicate that wealthier nondemocracies win at $2 \%$ below the rate of democracies that are not wealthier (significant below the 0.001 level). This minor but statistically significant difference suggests that democracy has a slightly greater impact

\footnotetext{
${ }^{9}$ Reiter and Stam also use COW's relative capability measure as a proxy for wealth. Our GDP measure is correlated with Capabilities at $r=0.90$, but Rosen's revenue measure is correlated with Capabilities at $r=0.45$. Concerns with collinearity only apply to the probit and hazard analyses.

${ }^{10}$ Victories of wealthy democracies include the United States in the Mexican-American/Spanish-American Wars, and Boxer Rebellion; Greece in the Second Balkan War; the UK/US in World War I; Czechoslovakia in the Hungarian-Allies War; the United States against Japan/Germany/Italy in World War II; India in the Bangladesh War; Turkey in the Turco-Cypriot War; the UK in the Falklands War; and the UK/US in the Gulf War.

11 These include Palestine 1948, Sinai 1956, Six Day 1967, October 1973 (two cases), Israeli-Egyptian 1969-1970, Israeli-Syrian 1982 (Lebanon War).

12 These include UK/France in the Boxer Rebellion; Greece in the First Balkan War; France/Greece in World War I; Poland in the Russo-Polish War; and the UK vs Germany/Italy in World War II.

13 These include the Greco-Turkish War 1897; Germany-Belgium World War I; Germany vs Belgium/Holland/Denmark/Norway 1940; the SinoIndian, and Turco-Cypriot War.
}

TABLE 1. Relationship Between Wealth, Democracy, and War Outcomes

\begin{tabular}{lcccccr}
\hline & \multicolumn{2}{c}{ Victory } & & \multicolumn{2}{c}{ Defeat } \\
\cline { 2 - 3 } & $\begin{array}{c}\text { More } \\
\text { Wealth }\end{array}$ & $\begin{array}{c}\text { Less } \\
\text { Wealth }\end{array}$ & & $\begin{array}{c}\text { More } \\
\text { Wealth }\end{array}$ & $\begin{array}{c}\text { Less } \\
\text { Wealth }\end{array}$ & Total \\
\hline Democratic & 32 & 15 & & 0 & 8 & 55 \\
Not Democratic & 49 & 28 & & 29 & 69 & 175 \\
Total & 81 & 43 & & 29 & 77 & 230 \\
\hline
\end{tabular}

$\left(\right.$ Note. Pearson $\chi^{2}(3)=30.5228, \operatorname{Pr}=0.001$; Fisher's Exact $=0.000$. $)$

TABle 2. Critical Test of Wealth, Democracy, and War Outcomes

\begin{tabular}{lcccc}
\hline Democratic & $\begin{array}{c}\text { More } \\
\text { Wealth }\end{array}$ & $\begin{array}{c}\text { Prediction of Democratic } \\
\text { Victory Thesis }\end{array}$ & $\begin{array}{c}\text { Prediction of } \\
\text { Wealth Thesis }\end{array}$ & $\begin{array}{c}\text { Actual Rate } \\
\text { of Victory (\%) }\end{array}$ \\
\hline Yes & Yes & Victory & Victory & 100 \\
Yes & No & Victory & Defeat & 65 \\
No & Yes & Defeat & Victory & 63 \\
No & No & Defeat & Defeat & 29 \\
\hline
\end{tabular}

TABle 3. Relationship Between Relative Capabilities (Power), Democracy, and War Outcomes

\begin{tabular}{lccccrrr}
\hline & \multicolumn{2}{c}{ Victory } & & \multicolumn{3}{c}{ Defeat } \\
\cline { 2 - 3 } & More Power & Less Power & & More Power & Less Power & Total \\
\hline Democratic & 32 & 15 & & 0 & 8 & 55 \\
Not Democratic & 51 & 26 & & 18 & 80 & 175 \\
Total & 83 & 41 & & 18 & 88 & 230
\end{tabular}

$\left(\right.$ Note. Pearson $\chi^{2}(3)=29.6804$, Pr $=0.001 ;$ Fisher's Exact $=0.000$.

than wealth in determining victory; however, the almost identical impact of both factors on war victory helps us to understand why scholars are able to provide equally strong arguments and evidence in support of the view that democracy or wealth has a major impact on war outcomes.

Next, we examine the relationship between relative capabilities and democracy on war outcomes. As reported in Table 3, states that were both democratic and more powerful won $100 \%(32 / 32)$ of their wars. More powerful states won $82 \%(83 / 101)$ of their wars, which is just below the rate for democratic states (that is, $47 / 55$ or $85 \%$ ); however, more powerful nondemocracies won their wars at a greater rate $(51 / 69$ or $74 \%)$ than less powerful democracies won theirs (i.e. $15 / 23$ or $65 \%$ ). In a slight majority of cases, democracies won wars even when they were not as powerful as their adversaries (15/28 or $54 \%),{ }^{14}$ but in all cases $(8 / 8)$ of democratic defeat, the democracy was less powerful than its counterpart. ${ }^{15}$ Finally, states that were neither democratic nor more powerful have won only $25 \%(26 / 106)$ of their wars.

As before, we provide head-to-head tests of the relative rate of success when the two theses make opposite predictions, and we find that although the presence of both relative power and democracy ensures victory and the

\footnotetext{
14 These include France in the Boxer Rebellion; Greece in the Balkan Wars; the UK/France/Greece in World War I; Poland in the Russo-Polish War; the UK vs Germany/Italy 1940; the United States vs Germany/Italy 1942; Israel in the Palestine, Sinai, Six Day, War of Attrition, and October Wars (two

${ }^{15}$ These include the dyads listed in note 12 .
} cases). 
TABle 4. Critical Test of Relative Capabilities (Power), Democracy, and War Outcomes

\begin{tabular}{|c|c|c|c|c|}
\hline Democratic & More Power & $\begin{array}{l}\text { Prediction of } \\
\text { Democratic } \\
\text { Victory Thesis }\end{array}$ & $\begin{array}{l}\text { Prediction of } \\
\text { Realist Thesis }\end{array}$ & $\begin{array}{c}\text { Actual Rate } \\
\text { of Victory (\%) }\end{array}$ \\
\hline Yes & Yes & Victory & Victory & 100 \\
\hline Yes & No & Victory & Defeat & 65 \\
\hline No & Yes & Defeat & Victory & 74 \\
\hline No & No & Defeat & Defeat & 25 \\
\hline
\end{tabular}

TABle 5. Relationship Between Wealth, Relative Capabilities (Power), and War Outcomes

\begin{tabular}{lrrrrrrr}
\hline & \multicolumn{2}{c}{ Victory } & & \multicolumn{2}{c}{ Defeat } & \\
\cline { 2 - 3 } \cline { 5 - 6 } & More Power & Less Power & & More Power & Less Power & Total \\
\hline More Wealth & 75 & 6 & & 16 & 13 & 110 \\
Less Wealth & 8 & 35 & & 2 & 75 & 120 \\
Total & 83 & 41 & & 18 & 88 & 230 \\
\hline
\end{tabular}

(Note. Pearson $\chi^{2}(3)=128.9763, \operatorname{Pr}=0.001$; Fisher's Exact $=0.000$.

absence of both almost ensures defeat, more powerful states are more likely to win their wars whether they are democracies or not, but democratic states that are less powerful than their opponents lose their wars more often. These results suggest that relative power, more than democracy, determines victory in war.

Finally, we examine the relationship between relative capabilities and wealth on war outcomes. Table 5 shows that more powerful and wealthier states won $82 \%$ $(75 / 91)$ of their wars, and more powerful but less wealthy states won $80 \%(8 / 10)$ of their wars. ${ }^{16}$ This almost identical rate of victory for these two types of states suggests that greater wealth adds little to the propensity of more powerful states to win their wars. In addition, more powerful states won a greater percentage of their wars $(83 / 101$ or $82 \%)$ than wealthier states won theirs $(81 / 110$ or $74 \%)$. In contrast, less powerful but wealthier states won only $32 \%(6 / 19)$ of their wars, ${ }^{17}$ and states that were neither wealthier nor more powerful won only $34 \%$ $(35 / 103)$ of their wars. More telling is that in $89 \%$ of the cases $(16 / 18)$ in which more powerful states lost their wars, they were wealthier than their counterparts, which suggests that greater wealth is a poor substitute for relative capabilities. $^{18}$

In the head-to-head tests in Table 6 , it is clear that having both greater military capabilities and greater wealth is associated with a high likelihood of success in war, while the absence of both reduces the likelihood of victory by almost $50 \%$. Nevertheless, states that are more powerful but not wealthier win an appreciably greater percentage of their wars than states that are wealthier but less powerful. Therefore, stronger states are more likely to win their

16 These include El Salvador in the Central American War 1885; Bulgaria in the Serbo-Bulgarian War; the UK in the Boxer Rebellion; Nicaragua in the Central American War 1907; Germany in World War I; Tanzania in the Ugandan-Tanzanian War; Israel in the Lebanon War.

17 These include France in the Crimean War; Serbia and Greece in the Second Balkan War; the UK in World War I; the United States in World War II; and the USSR in World War II.

18 These include the Two Sicilies in the War of the Roman Republic; France in the Franco-Mexican and Franco-Prussian Wars; China in the SinoJapanese War; Russia in the Russo-Japanese and Russo-Polish Wars; Turkey in the First Balkan War; China in the Sino-Soviet and Manchurian Wars; Bolivia in the Chaco War; Italy opposing Greece in World War II; and Egypt in the first five Middle East Wars.
TABle 6. Critical Test of Wealth, Relative Capabilities (Power), and War Outcomes

\begin{tabular}{lcccc}
\hline More Power & $\begin{array}{c}\text { More } \\
\text { Wealth }\end{array}$ & $\begin{array}{c}\text { Prediction of } \\
\text { Realist Thesis }\end{array}$ & $\begin{array}{c}\text { Prediction of } \\
\text { Wealth Thesis }\end{array}$ & $\begin{array}{c}\text { Actual Rate } \\
\text { of Victory (\%) }\end{array}$ \\
\hline Yes & Yes & Victory & Victory & 81 \\
Yes & No & Victory & Defeat & 80 \\
No & Yes & Defeat & Victory & 32 \\
No & No & Defeat & Defeat & 32 \\
\hline
\end{tabular}

wars whether they are wealthier or not, but wealthier states that are not stronger than their opponents are more likely to lose their wars. In this way, the outcomes are consistent with the realist thesis across each of the four contingencies in Table 6 even when the predictions contradict those of the wealth thesis. In fact, states with greater wealth but fewer relative capabilities have a rate of success comparable to states with neither greater wealth nor greater capabilities. More than any of the other comparisons, it is clear that relative capabilities are a more powerful predictor to victory in war than wealth.

In sum, the contingency table analyses indicate that relative capabilities are a better predictor of victory than either democracy or wealth, while democracy has a slightly greater impact than wealth. These results provide preliminary support for the realist thesis, but more rigorous analyses are required to parse the relative impact of the variables on war victory. Therefore, we examine the claims of our rival theses using probit regression with robust standard errors. As in the previous analyses, we examine all interstate wars from 1816 to 2007 from the COW project, and the unit of analysis is the state participant in one of the 79 wars that have win/lose outcomes. The outcome variable is coded " 1 " if the state won the war and " 0 " if it lost. Our variables are identical to those of Reiter and Stam's (1998, 2002), with the exception of the variables for wealth, which the authors did not include in their analyses. We use two different wealth variables. The initial GDP measure (Wealth-GDP) is a continuous variable, which captures the relative wealth of the state in relation to all war participants and is based on GDP information derived primarily from Maddison (2003). We also construct a dichotomous wealth variable (Wealth-Rosen), which takes the value of " 1 " for wealthier states and " 0 " otherwise and indicates whether the state was on the wealthier side in the war based primarily on revenue information derived from Rosen (1972).

The remaining variables are from Reiter and Stam (2002) and include their two democracy variables, Democracy*Initiation and Democracy*Target, which gauge the extent to which initiators and/or targets were democratic, and take the value of the product of Democracy, which is a continuous variable measured as noted previously, and a dichotomous initiation (Initiation) or target (Target) variable that measures whether a state initiated or was the target of the war as determined by COW criteria. ${ }^{19} \mathrm{Capa}$ bilities takes the value of the CINC score from COW. Alliances is a continuous variable, which measures the relative capabilities that the country's allies (if any) made to the war (based on COW capabilities data). Quality Ratio is a continuous variable that measures the extent of expenditure per troop (based on COW data), while Terrain is a continuous variable capturing the extent to which the

\footnotetext{
19 Although Bayer and Bernhard (2010) argue that democracy should be measured as a binary variable, to maintain consistency with their research, we utilize Reiter and Stam's continuous measure.
} 
environment affects the speed of troop movement, with higher values indicating more open and flat terrain (Reiter and Stam 2002:43). Given that terrain influences the effectiveness of a chosen strategy, the authors include an interaction variable, Strategy*Terrain. Strategy is coded using four binary variables from Stam (1996), which gauge the effectiveness of belligerents' war-fighting strategy given the operational environment and the strategy of their adversaries. Strategies are ranked by their presumed effectiveness when employed in the offense and in the face of opposing strategies in the defense; thus, Strategy 1 is more effective than Strategy $2, \ldots$, Strategy $4 .{ }^{20}$

\section{Determining War Outcomes: Probit Analyses}

The findings in Table 7 replicate Reiter and Stam's (2002:45) Model 4 and reveal that both democratic initiators and targets are more likely to win their wars, while autocratic regimes are more likely to lose their wars. ${ }^{21}$ We also find that initiators-in general, states with greater relative capabilities and those that receive greater assistance from allies-are also more likely to win their wars while those with the opposite characteristics are more prone to defeat. Both Terrain and Strategy*Terrain are significantly associated with war victory (the former negatively and the latter positively). In addition, each of the strategy variables is positively and significantly associated with military victory. All of these results are consistent with Reiter and Stam's previous findings.

Equation 2 drops Capabilities and adds Wealth-Rosen, and we find that the latter has a significant positive impact on war victory, and so do the democracy variables. ${ }^{22}$ However, the model's goodness of fit is not as good as Equation 1. ${ }^{23}$ In Equation 3, we bring Capabilities back into the model that includes Wealth-Rosen. This model does not suffer from collinearity problems between the two variables and allows for a clearer examination of the independent impact of wealth on war victory controlling for capability. The results of Equation 3 show that the impact of both capabilities and democracy is robust, but that of wealth is not since the coefficient for Wealth-Rosen is not significant. It may be that the impact of wealth on war outcomes is not independent of the impact of relative capabilities, and the results of Equation 4 seem to support this view since replacing Wealth-Rosen with Wealth-GDP and dropping Capabilities from the model result in wealth attaining significance. But Equation 5 includes both Wealth-GDP and Capabilities, and both variables are significant, which demonstrates that the impact of each variable on war outcomes is robust for the inclusion of the other variable in the same model. In sum, the findings from these models indicate that Capabilities, Democracy*Initiation, Democ-

\footnotetext{
${ }^{20}$ For a fuller discussion of each strategy and rationale, see Stam (1996). Like Rosen (1972), we controlled for the impact of relative battle deaths (Deaths) utilizing COW data on the number of troops killed in war, and we found that Deaths had a consistent negative impact on war victory and was statistically significant in Tables 7 and 8 but not in models 14 and 15 of Table 10 or Table 11.

${ }^{21}$ Reiter and Stam (2002) provide a non-monotonic polynomial estimation, but goodness-of-fit tests prefer the linear model over the polynomial model-just as Downes (2009a) found previously-and when Capabilities and Wealth-GDP are in the model, the polynomial variables are either nonsignificant or barely significant at the $10 \%$ level. The graph of the marginal impact of Democracy in Figure 1 is similar to theirs (Reiter and Stam 1998: note 17; Reiter and Stam 2002:32-33).

${ }^{22}$ Including both Wealth-GDP and Wealth-Rosen, their high collinearity precludes them from attaining statistical significance, but they were positively associated with war victory.

23 AIC and BIC gauge the fit of competing models, with a lower score denoting a better fitting model.
}

racy*Target, and Wealth-GDP are consistently, positively, and significantly associated with war victory.

In Equations 6-10 in Table 8, we replace Democracy*Initiation and Democracy*Target with Democracy. ${ }^{24}$ This specification allows us to estimate the impact of democracy on a state's probability of war victory more generally-and more directly-from our models, instead of focusing on the relative impact of democracy in initiator and target success, separately. The goodness-of-fit measures indicate that the models with the single democracy variable have a consistently better fit than those with the two democracy variables, and the models that include Capabilities have a better fit than those without it. The results in Table 8 are consistent with the previous findings and further demonstrate that the impact of relative capability, democracy, and wealth on military victory is positive, robust, and significant; but, statistical significance does not convey their substantive impact. In order to determine that, we estimate the predicted probabilities of the variables based on the results reported in Model 10 of Table 8 . Figure 1 reflects the changes in the probability of victory when the values of Democracy, Wealth-GDP, and Capabilities, respectively, are varied across the range of their values, while holding the remaining continuous variables at their means and dichotomous variables at $0 .{ }^{25}$ For example, when Democracy is at -5 , which is only barely above the threshold of an autocratic regime on the Polity scale, the state has a probability of victory of about $47 \% .{ }^{26}$ For a state scoring +5 , which is just below the threshold of a democratic regime on the Polity scale, the chances of victory are $71 \%$. Interestingly, the difference in the probability of victory for states that are minimally democratic $(74 \%)$ to those that are maximally democratic $(81 \%)$ is only $7 \%$.

While these effects are substantial, the impact of Democracy is less than that of Wealth-GDP. For example, if a country's Wealth-GDP is $50 \%$ of the Wealth-GDP of all war participants, its probability of victory is $66 \%{ }^{27}$ This relationship obtained in World War II, when in 1941 the USSR had $51 \%$ to Germany's $49 \%$, and in 1962, China had $52 \%$ compared to India's $48 \%$. A country with $75 \%$ of the total wealth of the war participants has a probability of victory of $80 \%$, as in 1823 when France had $76 \%$ of the wealth in its war with Spain that the former won. A country with approximately $95 \%$ of the wealth of the belligerents has a $88 \%$ prospect of victory, such as in 1941 when Germany had $95 \%$ of the total wealth compared to Yugoslavia, and in 1956 the USSR had 96\% in comparison to Hungary, while in 1974 prior to its war in Cyprus, which it won, Turkey had $98 \%$ of the wealth.

The substantive impact of Capabilities is even more pronounced as it approaches its maximum value. For example, if a country has $50 \%$ of the relative capabilities as compared to its adversaries, its probability of victory is $70 \%{ }^{28}$ This relationship is evident in the Sino-Soviet War, when in 1929 the USSR had $50 \%$ of the capabilities in its victory over China. For a country with $75 \%$ of the capabilities, the probability of victory is $86 \%$ - as in 1982 when the UK had $75 \%$ of the capabilities as compared to

\footnotetext{
${ }^{24}$ Results using a binary measure of democracy and Doyle's liberal democracy measure were consistent with those reported above.

${ }^{25}$ The baseline strategy, OADA/DAOA, is set at 1 .

${ }^{26}$ Setting Initiation at 1 and Democracy at -5 , the probability of victory is $80 \%$.

27 Setting Initiation at 1 and Wealth-GDP at $50 \%$, the probability of victory is $90 \%$. $92 \%$.
} 
TABLE 7. Probit Models of Interstate War Outcomes

\begin{tabular}{|c|c|c|c|c|c|}
\hline & Model 1 & Model 2 & Model 3 & Model 4 & Model 5 \\
\hline Democracy*Initiation & $0.068(0.027)^{*}$ & $0.058(0.023) *$ & $0.070(0.027)^{* *}$ & $0.063(0.027) *$ & $0.069(0.027)^{*}$ \\
\hline Democracy*Target & $0.063(0.027) *$ & $0.043(0.028)$ & $0.060(0.029)^{*}$ & $0.052(0.028)^{\dagger}$ & $0.059(0.029)^{*}$ \\
\hline Initiation & $1.029(0.302)^{* *}$ & $0.692(0.297)^{*}$ & $0.944(0.303)^{* *}$ & $0.806(0.315)^{*}$ & $0.937(0.306)^{* *}$ \\
\hline Capabilities & $3.654(0.496) * *$ & & $3.289(0.638) * *$ & & $2.283(0.865)^{* *}$ \\
\hline Alliances & $4.243(0.622) * *$ & $1.140(0.469)^{*}$ & $3.842(0.803) * *$ & $3.998(0.567) * *$ & $4.356(0.615)^{* *}$ \\
\hline Quality Ratio & $0.004(0.003)$ & $0.001(0.003)$ & $0.004(0.003)$ & $0.003(0.003)$ & $0.004(0.003)$ \\
\hline Terrain & $-11.581(3.244) * *$ & $-8.774(2.650)^{* *}$ & $-11.336(3.152) * *$ & $-11.046(3.061) * *$ & $-11.606(3.316) * *$ \\
\hline Strategy*Terrain & $3.841(1.087)^{* *}$ & $2.832(0.865)^{* *}$ & $3.740(1.055) * *$ & $3.672(1.001)^{* *}$ & $3.853(1.100) * *$ \\
\hline Strategy 1 & $7.982(3.100) *$ & $5.429(2.611)^{*}$ & $7.808(3.060)^{*}$ & $7.998(2.973) * *$ & $8.242(3.176) * *$ \\
\hline Strategy 2 & $4.619(2.390)^{\dagger}$ & $3.184(1.852)^{\dagger}$ & $4.530(2.318)^{\dagger}$ & $4.594(2.107) *$ & $4.753(2.389)^{*}$ \\
\hline Strategy 3 & $3.828(1.559) *$ & $2.608(1.296)^{*}$ & $3.748(1.531)^{*}$ & $3.915(1.461)^{* *}$ & $3.983(1.586)^{*}$ \\
\hline Strategy 4 & $2.493(1.005)^{*}$ & $1.245(0.999)$ & $2.414(1.006)^{*}$ & $2.873(1.056)^{* *}$ & $2.790(1.063) * *$ \\
\hline Wealth-Rosen & & $1.289(0.252) * *$ & $0.281(0.350)$ & & \\
\hline Wealth-GDP & & & & $3.670(0.479) * *$ & $1.729(0.842)^{*}$ \\
\hline Constant & $-5.960(1.805) * *$ & $-3.352(1.447) *$ & $-5.763(1.777) * *$ & $-5.971(1.692) * *$ & $-6.244(1.835)^{* *}$ \\
\hline AIC & 0.758 & 0.868 & 0.763 & 0.77 & 0.753 \\
\hline $\mathrm{BIC}$ & -1031.8 & -1006.5 & -1027.14 & $-1,029$ & -1029.49 \\
\hline Observations & 230 & 230 & 230 & 230 & 230 \\
\hline Log Likelihood & -74.12 & -86.78 & -73.74 & -75.54 & -72.57 \\
\hline Wald $\chi^{2}$ & 108.95 & 76.87 & 117.48 & 117.4 & 112.83 \\
\hline
\end{tabular}

(Note. Robust standard errors in brackets; $\left.{ }^{\dagger} p \leq .10 ; * p \leq .05 ; * * p \leq .01.\right)$

TABLE 8. Probit Models of Interstate War Outcomes

\begin{tabular}{|c|c|c|c|c|c|}
\hline & Model 6 & Model 7 & Model 8 & Model 9 & Model 10 \\
\hline Democracy & $0.066(0.020) * *$ & $0.050(0.018)^{* *}$ & $0.065(0.021)^{* *}$ & $0.058(0.020)^{* *}$ & $0.064(0.021) * *$ \\
\hline Initiation & $1.016(0.286)^{* *}$ & $0.656(0.269)^{*}$ & $0.921(0.289)^{* *}$ & $0.780(0.291)^{* *}$ & $0.911(0.292)^{* *}$ \\
\hline Capabilities & $3.655(0.502) * *$ & & $3.299(0.640) * *$ & & $2.293(0.869)^{* *}$ \\
\hline Alliances & $4.246(0.625)^{* *}$ & $1.155(0.465)^{*}$ & $3.862(0.797) * *$ & $4.003(0.566)^{* *}$ & $4.357(0.617)^{* *}$ \\
\hline Quality Ratio & $0.004(0.003)$ & $0.002(0.003)$ & $0.004(0.003)$ & $0.003(0.003)$ & $0.004(0.003)$ \\
\hline Terrain & $-11.563(3.240)^{* *}$ & $-8.704(2.603) * *$ & $-11.305(3.146) * *$ & $-11.009(3.033) * *$ & $-11.572(3.305) * *$ \\
\hline Strategy*Terrain & $3.838(1.086)^{* *}$ & $2.816(0.853)^{* *}$ & $3.735(1.054)^{* *}$ & $3.667(0.995)^{* *}$ & $3.847(1.097)^{* *}$ \\
\hline Strategy 1 & $7.978(3.092) * *$ & $5.402(2.597)^{*}$ & $7.805(3.058)^{*}$ & $7.995(2.968)^{* *}$ & $8.239(3.171)^{* *}$ \\
\hline Strategy 2 & $4.611(2.389)^{\dagger}$ & $3.157(1.840)^{\dagger}$ & $4.519(2.321)^{\dagger}$ & $4.582(2.104)^{*}$ & $4.744(2.392)^{*}$ \\
\hline Strategy 3 & $3.834(1.550)^{*}$ & $2.628(1.300)^{*}$ & $3.765(1.527)^{*}$ & $3.934(1.465)^{* *}$ & $4.001(1.583)^{*}$ \\
\hline Strategy 4 & $2.524(1.008)^{*}$ & $1.279(1.002)$ & $2.453(1.012)^{*}$ & $2.912(1.064)^{* *}$ & $2.827(1.069)^{* *}$ \\
\hline Wealth-Rosen & & $1.280(0.248)^{* *}$ & $0.269(0.343)$ & & \\
\hline Wealth-GDP & & & & $3.665(0.475)^{* *}$ & $1.709(0.829)^{*}$ \\
\hline Constant & $-5.962(1.798) * *$ & $-3.362(1.444)^{*}$ & $-5.774(1.772) * *$ & $-5.983(1.691)^{* *}$ & $-6.250(1.831)^{* *}$ \\
\hline Observations & 230 & 230 & 230 & 230 & 230 \\
\hline Log Likelihood & -73.96 & -86.75 & -73.61 & -75.45 & -72.45 \\
\hline Wald $\chi^{2}$ & 101.56 & 76.75 & 110.13 & 116.62 & 109.57 \\
\hline
\end{tabular}

(Note. Robust standard errors in brackets; $\left.{ }^{\dagger} p \leq .10 ; * p \leq .05 ; * * p \leq .01.\right)$

Argentina. A country with about $80 \%$ of the capabilities has an even greater probability of victory: In 1823, France had $79 \%$ of the capabilities as compared to Spain, which it defeated, and in 1971, India had $81 \%$ of the capabilities relative to Pakistan, which it defeated. At $95 \%$ of the capabilities, the probability of victory is $94 \%$ as in Germany's defeat of Belgium in 1940.

In sum, the findings from the probit analyses demonstrate that Capabilities has the largest substantive impact on war victory. At its (relative) maximum value of $98 \%$, Capabilities is associated with a $95 \%$ probability of victory, while Wealth-GDP at its maximum value is associated with an $89 \%$ probability of victory. Democracy has a weaker-though still impressive-impact on war victory. At its maximum value, it is associated with an $81 \%$ probability of victory; nonetheless, this is the lowest probability of victory for our three key variables of interest. In fact, the $81 \%$ probability of victory that Democracy attains at its maximum value, Capabilities achieves at a value of 0.67 , which represents only a moderately more powerful state in a dyadic war (for example, North Vietnam over South Vietnam in the Vietnam War), and Wealth achieves at a value of 0.77 (for example, France-Germany in World War II). The findings up to this point provide greater support for realist claims.

\section{Determining War Outcomes: Hazard Analyses}

An important corollary of the democratic victory thesis is that democracies are more likely to win their wars because they select themselves into easier contests marked by favorable asymmetries in capabilities, quality of troops and technology, wealth, and/or population, and, as a result fight, shorter wars. Previous work has found that democracies, on average, fight wars of roughly 18-month duration and that they are more likely to win these wars (Stam 1996; Bennett and Stam 1998). Some studies have attributed the success of democracies in wars 


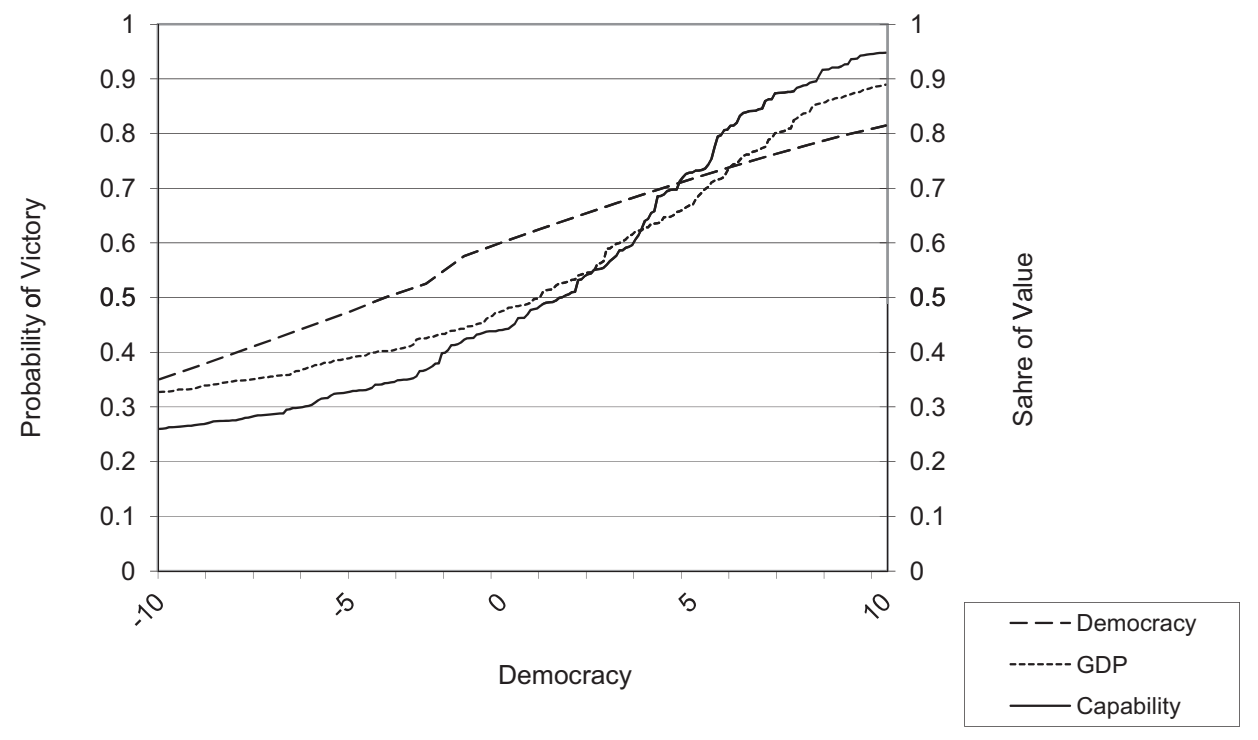

FIG 1. Relative Impact of Democracy, Wealth, and Capabilities on War Victory

to their employment of more effective strategies that facilitate quick victory (Reiter and Meek 1999). Given that the ability to win a war in a relatively shorter period of time implies greater war-fighting ability-especially since the median length of wars from 1816 to 1991 is about 11 months (Bennett and Stam 1996), it follows that a tendency to fight shorter wars should characterize the most successful states. The democratic victory thesis suggests that fighting shorter wars is a hallmark of democracies; however, we find that democracies are not more likely to win their wars as compared to states with greater capabilities-and possibly wealthier states, as well. This begs the question of whether fighting shorter wars is a unique attribute of democracies or is more likely for militarily stronger or wealthier states. ${ }^{29}$ Therefore, in this section, we examine the relationship between these variables and the duration of wars.

Survival or hazard analyses examine the time it takes for an event to occur, and a key feature of such analyses is the hazard rate, which in our case is the instantaneous rate at which a war ends at time $t$, given that it has survived until time $t$. Hazard model coefficients and standard errors can be interpreted much like our probit coefficients in terms of their statistical significance; however, direct interpretation of the estimated $\beta$ coefficients is difficult due to hazard rate formulas and the presence of nonlinearity. But we can use the coefficients to produce marginal effects of our covariates and also use them to predict durations for any circumstance we can specify with our variables. Following Bennett and Stam (1996, 2006), we utilize a Weibull specification for the hazard analysis. The Weibull distribution can be expressed as $h(t)=\lambda \mathrm{p}(\lambda \mathrm{t})^{\mathrm{p}^{-1}}$, where $h(t)$ represents the hazard rate at time $t$. Parameter, $\lambda$, is a scale parameter, and $\mathrm{p}$ is the shape parameter. Covariates affect the scale parameter, but the shape parameter remains constant. When the shape parameter is between 0 and 1 , the hazard rate is decreasing monotonically over time, whereas if this parameter is greater than 1, then the hazard rate is increasing monotonically over time. The impact of covariates on the hazard rate is captured through $\lambda=e^{-(\beta \mathrm{Xi})}$ To

${ }^{29}$ For Mearsheimer (1983), fighting shorter wars is a preference of leaders, in general. put it simply, in the subsequent analyses, positive $\beta$ coefficients predict longer duration and negative coefficients predict shorter duration. Data are from Bennett and Stam (2006), and all operationalizations and case selection information are from Bennett and Stam (1996). The war dyad year is the unit of analysis, and the data set contains one observation per year of each war, which is necessary for our use of time-varying covariates in the hazard analyses, resulting in 181 cases and information on 87 wars.

Equation 11 in Table 9 replicates the original Bennett and Stam (1996) model, which included a relative capabilities variable operationalized as the ratio of the relative capabilities of the stronger state to the sum of the relative capabilities of the dyad and was labeled balance of forces in the original study, but we will refer to as Capabilities for consistency, and two democracy variables including a Polity-based Democracy variable and a repression variable, Repression, which is assumed to be inversely related to democracy-but not perfectly so (Bennet and Stam 1996:248-249). ${ }^{30}$ The original study did not include a wealth variable, which we add in Equations 12 and 13 . Following a similar approach to Bennett and Stam's (1996) construction of their balance of forces variable, we created a variable, Wealth-GDP, which takes the value of the ratio of the GDP of the wealthier state to the sum of the GDPs of both states in the dyad. ${ }^{31}$ In Equation 12, Capabilities is dropped; however, in these models, the coefficient of Wealth-GDP is significant whether Capabilities is included or not. The correlation between the wealth and capability variable is 0.55 . Given that negative signs on the coefficients mean that the hazard rate is increasing and that the duration is decreasing, the results from both equations demonstrate that each of our key factors is significantly associated with an increasing hazard rate, and thus wars of shorter duration. Therefore, while the results corroborate previous findings that democracies fight shorter wars, they also support the view that wealthier as well as more powerful states also fight shorter wars.

\footnotetext{
${ }^{30}$ Bennett and Stam (1996:248) reported a correlation of $r=-0.64$ between the two variables.

31 Bennett and Stam's (1996) balance of forces variable relies on a relative capabilities measure adjusted for distance; however, the balance of wealth variable is not adjusted for distance. The correlation between the balance of forces and wealth variables is $r=0.55$.
} 
TABLE 9. Hazard Analysis of Interstate War Outcomes

\begin{tabular}{|c|c|c|c|}
\hline & Model 11 & Model 12 & Model 13 \\
\hline Democracy & $-0.100(0.058)^{\dagger}$ & $-0.107(0.062)^{\dagger}$ & $-0.085(0.058)$ \\
\hline Wealth-GDP & & $-2.493(0.898) * *$ & $-1.386(0.758)^{\dagger}$ \\
\hline Capability & $-3.884(1.252) * *$ & & $-3.125(1.176) * *$ \\
\hline Strategy: OADM & $1.226(0.828)$ & $1.189(0.834)$ & $1.075(0.808)$ \\
\hline Strategy: OADA & $1.563(0.853)^{\dagger}$ & $1.746(0.788)^{*}$ & $1.575(0.823)^{\dagger}$ \\
\hline Strategy: OADP & $3.331(1.708)^{\dagger}$ & $3.479(1.522)^{*}$ & $3.467(1.593) *$ \\
\hline Strategy: OPDA & $4.695(4.234)$ & $4.769(4.115)$ & $5.028(4.140)$ \\
\hline Terrain & $-0.502(3.947)$ & $-1.02(3.762)$ & $-0.406(3.835)$ \\
\hline Terrain*Strategy & $-0.237(1.069)$ & $-0.186(1.037)$ & $-0.292(1.042)$ \\
\hline Total Military Personnel & $0.094(0.034)^{* *}$ & $0.119(0.038)^{* *}$ & $0.095(0.034) * *$ \\
\hline Total Population & $0.76(0.556)$ & $0.391(0.518)$ & $0.588(0.552)$ \\
\hline Population Ratio & $0.009(0.012)$ & $0.002(0.013)$ & $0.014(0.014)$ \\
\hline Quality Ratio & $0.004(0.002)^{*}$ & $0.005(0.002)^{*}$ & $0.004(0.002) *$ \\
\hline Surprise & $-0.175(0.666)$ & $0.127(0.781)$ & $-0.058(0.682)$ \\
\hline Salience & $0.415(0.198)^{*}$ & $0.458(0.188)^{*}$ & $0.387(0.200)^{\dagger}$ \\
\hline Repression & $-0.212(0.121)^{\dagger}$ & $-0.234(0.126)^{\dagger}$ & $-0.205(0.119)^{\dagger}$ \\
\hline Previous Disputes & $-0.004(0.054)$ & $-0.029(0.052)$ & $-0.021(0.052)$ \\
\hline Number of States & $-0.089(0.078)$ & $-0.111(0.077)$ & $-0.09(0.079)$ \\
\hline Constant & $2.820(1.514)^{\dagger}$ & $1.825(1.264)$ & $3.361(1.559)^{*}$ \\
\hline \multirow[t]{2}{*}{$p$ (duration parameter) } & 0.889 & 0.878 & 0.902 \\
\hline & 0.083 & 0.085 & 0.087 \\
\hline Log Likelihood & -148.2 & -150.1 & -147.3 \\
\hline Observations & 181 & 181 & 181 \\
\hline
\end{tabular}

(Note. Robust standard errors in brackets; $\left.{ }^{\dagger} p \leq .10 ; * p \leq .05 ; * * p \leq .01.\right)$

Just as Bennett and Stam (1996) uncovered, relative military capabilities has the strongest impact on the duration of wars. Given the nonlinearities in the estimation of hazard rates, the coefficients are not directly interpretable as an OLS coefficient would be, but the interpretation of the direction and significance level of coefficients are similar, and the coefficients of Capabilities, Democracy, and Wealth-GDP are each negatively and significantly associated with the hazard rate-although Democracy is just barely significant. In Equation 13, which includes all of the key variables, both Capabilities and Wealth-GDP have a robust impact on the duration of war, but the coefficient of Democracy is not significant. Thus, the inclusion of capabilities and wealth in the same model washes out the impact of democracy on war duration. The nonsignificance of democracy as a predictor to war duration challenges the view that democracies are uniquely predisposed to fight shorter wars and supports the argument that the preference for shorter wars obtains across regime types. The contrast with Bennett and Stam's findings is not a result of collinearity between wealth and democracy $(r=0.18)$ or wealth and capability $(r=0.55)$, but probably results from limits of their data, which extend only to 2005-excluding subsequent years of the US-Iraq War and the US-Afghan War, in which in both cases, democracies fought protracted wars.

We also graphically depict the effect of changes in the values of our predictors on the survival of the outcome up to that time. While hazard functions indicate the rate at which units fail, survival functions reflect the proportion of wars that are surviving beyond time $t$. The two functions are related: the hazard rate is the probability density function divided by the survival function. Figure 2 depicts the survival functions of our statistically significant predictors as their values range from their mean to their maximum. ${ }^{32}$ The graph shows that when our variables are at their

${ }^{32}$ No state has $100 \%$ of capabilities or wealth so we estimate $95 \%$ of their maximum values. means, those wars are longest, and when each is at $95 \%$ of their maximum values, those wars are shortest. The placement of the interior plot lines of the graph gives a visual sense of the degree to which changes in the values of the variables result in changes in the duration of the wars. The plots of changes in the survival functions reinforce the main finding from the previous analyses: Relative military capabilities have the greatest and most robust impact on war outcomes (that is, victory and duration) as compared to democracy and wealth. Changing Capabilities from its mean to maximum value results in the largest shift in the survival function from the baseline curve as compared to the shift from changes in the value of Wealth-GDP, which is the only other significant variable among the three variables of interest (Democracy is not significant). ${ }^{33}$

Conceptualizing these relationships in terms of differences in the expected months of war for the US-Iraq War of 2003 given different values of the key variables demonstrates the substantive impact of the relationships suggested by the hazard analyses. If we compute the expected months of war predicted by our model when the values of all of our key variables are set at their respective mean or modal values (the baseline model) and compare them to the expected months of war predicted by our model when our significant variables are set at $95 \%$ of their maximum values, we can get a better sense of the impact of changes in the values of our key variables on the duration of war. Therefore, we re-estimated Model 13 without the US-Iraq War of 2003, and for the baseline model, the expected duration of the war was 17 months. With wealth set at $95 \%$ holding other variables constant, the war's duration is 12 months. ${ }^{34}$ With relative military capabilities set at $95 \%$, war duration

\footnotetext{
${ }^{33}$ With Democracy at its maximum value that we observe in the data $(+17$ on Bennett and Stam's measure), its relative impact on war duration is almost indistinguishable from that of Capabilities; in fact, Democracy has a slightly larger impact albeit it is not statistically significant.

${ }_{34}$ Democracy is not significant, but at $95 \%$ of its maximum, ceteris paribus, duration is 9 months.
} 


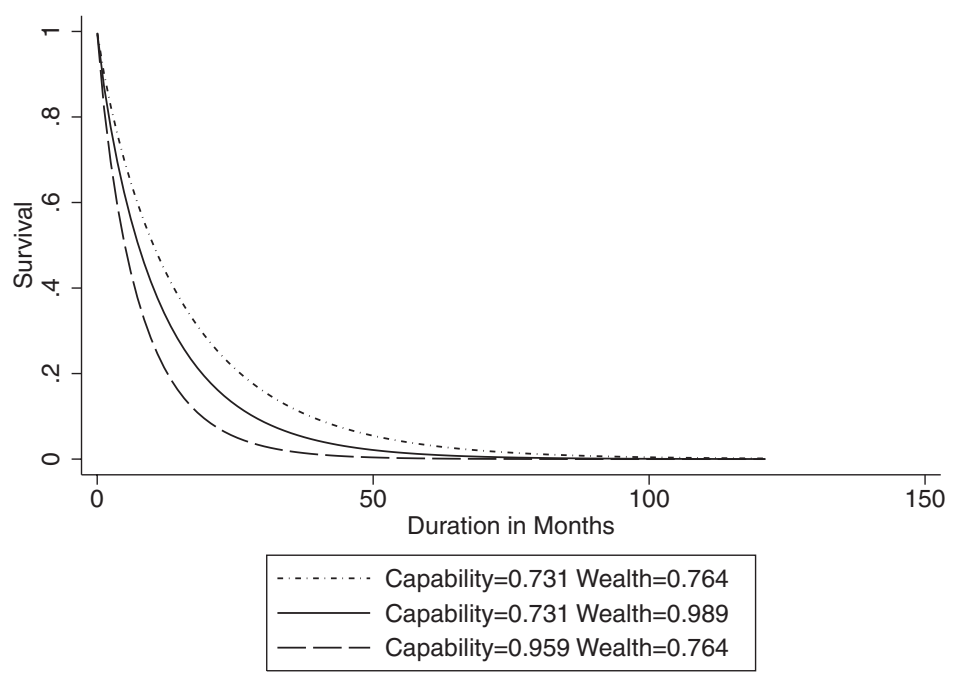

FIG 2. Relative Impact of Capabilities and Wealth on War Duration

is 8 months. It follows that the propensity to fight the shortest wars is the hallmark of more powerful states, and to a lesser extent wealthier states, while democracy is not significantly associated with war duration. In sum, the findings of the hazard analysis provide greater support for realist claims.

\section{Discussion}

Our most conclusive finding is that relative military capabilities have the most consistent, positive, substantive impact on victory in interstate war as compared to either wealth or democracy, and this finding supports realist claims. As noted above, there are two aspects of the democratic victory thesis: democracies-as compared to other regimes-are more likely to win their wars and democracy-as compared to other factors-is responsible for victory in interstate war. The first claim constitutes the main contention of the democratic victory thesis; our findings support this view as well. What we are unable to determine from our analyses thus far is the extent to which democracy is the determinant of democratic victory in war or some other unit-level attribute that just happens to be more prevalent in the democracies in our sample of wars as compared to nondemocracies. That is, rather than the war-fighting or war-selection attributes that democratic victory advocates emphasize are particular to democracies, it may be that states of any regime type that possess certain institutional capacities are more likely to win their wars. ${ }^{35}$ For example, Bueno de Mesquita et al. (2004) argue that democratic victory derives from the impact of the relatively larger size of the governing coalition, the selectorate, in democracies, which makes the leader's tenure dependent, inter alia, on the success of its foreign policies; as a result, these leaders are more selective in their choice(s) of targets and try harder to win the wars they fight. Initially, the authors find that states with larger governing coalitions increase their military effort during wartime (Bueno de Mesquita et al. 2004:257-258), but when they control for demographic factors and wealth, their selectorate variables are not significant even at the $10 \%$ level, and their results are even

\footnotetext{
${ }^{35}$ For example, re-estimating our probit models including a political legitimacy variable, we found that while it was positively and significantly associated with victory, the impact of Democracy was robust.
}

weaker when they substitute an explicit democracy variable for their selectorate variable.

In another study, Biddle and Long (2004:541) conclude that nonmaterial factors are largely responsible for the military effectiveness attributed to democracies. They find that the battlefield success of democracies results from their "superior human capital, civil-military relations, and cultural background," and controlling for these factors, democracies actually perform worse on the battlefield (Biddle and Long 2004:538). However, there are several problems in the study not least of which is the authors' reliance on the CHASE/HERO data set as the source of its main outcome variable-and several predictor variables, as well. As noted above, this data set has been criticized for a range of measurement errors and reliability problems (Desch 2002, 2008; Reiter and Stam 2002, 2003; Brooks 2003), and their data analyses include observations of battles from only 13 wars. Moreover, their main findings are not robust: Their human capital and civil-military relations variables are not consistently significant across their models. Further, their claim that Western states have greater battlefield success is overstated since two of the four variables coded for Western state battlefield effectiveness are not significant (Biddle and Long 2004:538); the other two proxy the United States in its wars with Japan and North Korea, and Israel in its Middle East wars. Nevertheless, Biddle and Long's analysis of the role of cultural factors in the military performance of democratic states-in light of recent findings on the applicability of the democratic peace outside the West (Goldsmith 2006; Powers 2006; Henderson 2009) - has implications for the presumed universality of the democratic victory thesis. That is, if democracy is responsible for the success of democratic states in war, then this quality of democracy should be evident for all democracies, and the democratic victory phenomenon should be universal.

To test the universality of the democratic victory phenomenon, we differentiate Western and non-Western democracies and re-estimate our probit analyses. The findings reported in Tables 10 and 11 include a disaggregated democracy variable, a regional variable, and the other variables from our basic probit model. The first adds the binary variable, Western, as well as Democracy, and the interaction, Western*Democracy, and the second adds Non-Western, Democracy, and the interaction, 
Table 10. Probit Models of Interstate War Outcomes

\begin{tabular}{|c|c|c|c|c|}
\hline & Model 14 & Model 15 & Model 16 & Model 17 \\
\hline Democracy & $1.353(0.552)^{*}$ & $1.138(0.597)^{\dagger}$ & $1.617(0.406)^{* *}$ & $1.255(0.355)^{* *}$ \\
\hline Western & $-0.138(0.273)$ & $-0.133(0.254)$ & & \\
\hline Democracy* & 0.264 & 0.117 & & \\
\hline Western & $(0.657)$ & $(0.682)$ & & \\
\hline Non-Western & & & $0.138(0.273)$ & $0.133(0.254)$ \\
\hline Democracy*Non-Western & & & $-0.264(0.657)$ & $-0.117(0.682)$ \\
\hline Initiation & $1.096(0.290) * *$ & $0.829(0.287)^{* *}$ & $1.096(0.290)^{* *}$ & $0.829(0.287)^{* *}$ \\
\hline Capabilities & $3.702(0.520) * *$ & & $3.702(0.520) * *$ & \\
\hline Alliances & $4.320(0.674)^{*}$ & $4.015(0.582)^{* *}$ & $4.320(0.674)^{* *}$ & $4.015(0.582) * *$ \\
\hline Quality Ratio & $0.003(0.003)$ & $0.003(0.003)$ & $0.003(0.003)$ & $0.003(0.003)$ \\
\hline Terrain & $-10.974(3.330) * *$ & $-10.494(3.059) * *$ & $-10.974(3.330) * *$ & $-10.494(3.059) * *$ \\
\hline Strategy*Terrain & $3.597(1.121)^{* *}$ & $3.456(1.015)^{* *}$ & $3.597(1.121)^{* *}$ & $3.456(1.015)^{* *}$ \\
\hline Strategy 1 & $7.239(3.240)^{*}$ & $7.389(3.059)^{*}$ & $7.239(3.240) *$ & $7.389(3.059) *$ \\
\hline Strategy 2 & $4.164(2.560)$ & $4.213(2.207)^{\dagger}$ & $4.164(2.560)$ & $4.213(2.207)^{\dagger}$ \\
\hline Strategy 3 & $3.673(1.634)^{*}$ & $3.786(1.497)^{*}$ & $3.673(1.634) *$ & $3.786(1.497)^{*}$ \\
\hline Strategy 4 & $2.561(1.058) *$ & $2.926(1.083)^{* *}$ & $2.561(1.058) *$ & $2.926(1.083) * *$ \\
\hline Wealth-GDP & & $3.617(0.482)^{* *}$ & & $3.617(0.482) * *$ \\
\hline Constant & $-6.075(1.883)^{* *}$ & $-6.019(1.719)^{* *}$ & $-6.213(1.896) * *$ & $-6.152(1.727)^{* *}$ \\
\hline Observations & 230 & 230 & 230 & 230 \\
\hline Log Likelihood & -71.93 & -74.15 & -71.93 & -74.15 \\
\hline Wald $\chi^{2}$ & 99.98 & 116 & 99.98 & 116 \\
\hline
\end{tabular}

(Note. Robust standard errors in brackets; ${ }^{\dagger} p \leq .10 ; * p \leq .05 ; * * p \leq .01$.)

Table 11. Probit Models of Interstate War Outcomes

\begin{tabular}{|c|c|c|c|c|}
\hline & Model 18 & Model 19 & Model 20 & Model 21 \\
\hline Democracy & $0.615(0.420)$ & $0.394(0.465)$ & $2.149(0.580) * *$ & $1.883(0.594)^{* *}$ \\
\hline Western including Israel & $-0.149(0.276)$ & $-0.141(0.259)$ & & \\
\hline Democracy*Western including Israel & $1.535(0.705)^{*}$ & $1.489(0.754)^{*}$ & & \\
\hline Non-Western excluding Israel & & & $0.149(0.276)$ & $0.141(0.259)$ \\
\hline Democracy*Non-Western excluding Israel & & & $-1.535(0.705)^{*}$ & $-1.489(0.754)^{*}$ \\
\hline Initiation & $1.154(0.292) * *$ & $0.879(0.286)^{* *}$ & $1.154(0.292)^{* *}$ & $0.879(0.286)^{* *}$ \\
\hline Capabilities & $3.721(0.526)^{* *}$ & & $3.721(0.526)^{* *}$ & \\
\hline Alliances & $4.344(0.689) * *$ & $4.042(0.594)^{* *}$ & $4.344(0.689) * *$ & $4.042(0.594)^{* *}$ \\
\hline Quality Ratio & $0.003(0.003)$ & $0.003(0.003)$ & $0.003(0.003)$ & $0.003(0.003)$ \\
\hline Terrain & $-10.713(3.358) * *$ & $-10.205(3.154) * *$ & $-10.713(3.358) * *$ & $-10.205(3.154) * *$ \\
\hline Strategy*Terrain & $3.480(1.138)^{* *}$ & $3.333(1.054)^{* *}$ & $3.480(1.138)^{* *}$ & $3.333(1.054)^{* *}$ \\
\hline Strategy 1 & $6.753(3.311)^{*}$ & $6.855(3.216)^{*}$ & $6.753(3.311)^{*}$ & $6.855(3.216)^{*}$ \\
\hline Strategy 2 & $3.822(2.622)$ & $3.871(2.331)^{\dagger}$ & $3.822(2.622)$ & $3.871(2.331)^{\dagger}$ \\
\hline Strategy 3 & $3.554(1.648)^{*}$ & $3.678(1.545)^{*}$ & $3.554(1.648)^{*}$ & $3.678(1.545)^{*}$ \\
\hline Strategy 4 & $2.511(1.093)^{*}$ & $2.905(1.114)^{* *}$ & $2.511(1.093)^{*}$ & $2.905(1.114)^{* *}$ \\
\hline Wealth-GDP & & $3.684(0.488) * *$ & & $3.684(0.488) * *$ \\
\hline Constant & $-5.907(1.906) * *$ & $-5.881(1.768) * *$ & $-6.056(1.921)$ & $-6.023(1.776)$ \\
\hline Observations & 230 & 230 & 230 & 230 \\
\hline Log Likelihood & -70.62 & -72.69 & -70.62 & -72.69 \\
\hline Wald $\chi^{2}$ & 91.7 & 107.95 & 91.7 & 107.95 \\
\hline
\end{tabular}

(Note. Robust standard errors in brackets; ${ }^{\dagger} p \leq .10 ; * p \leq .05 ; * * b \leq .01$.)

Non-Western*Democracy. Western states are those of Western Europe, North America, and Australia, and others are non-Western. ${ }^{36}$ There are 101 cases of Western states in interstate wars, 129 cases of non-Western states in wars, as well as 37 cases of Western democracy and 18 cases of non-Western democracy (that is, cases including Armenia, Greece, India, Israel, Pakistan, and Turkey).

The results of Equations 14 and 17 of Table 10 indicate that Democracy is consistently, positively, and significantly associated with victory, while Western, Western*Democracy, Non-Western, and Non-Western*Democracy

\footnotetext{
${ }^{36}$ The classification of states follows Henderson and Tucker (2001) and Leng and Regan (2003).
}

are not, which seems to confirm the view that democratic victory is a universal phenomenon; however, since there is some debate on whether Israel should be classified as a Western country (Henderson and Tucker 2001) and its war record includes a preponderance of non-Western democratic victories, we also wanted to determine the robustness of these findings if Israel was moved from the non-Western to the Western category. When this is done, the results of Equations 18 and 19 in Table 11, which includes Western, Democracy, and Western*Democracy, suggest that the previous findings are not robust because only the coefficient for Western*Democracy is positive and significant. Moreover, in Equations 20 and 21, which include Non-Western, Democracy, and Non-Western*Democracy, the 
coefficient of Democracy is positive and significant, but the coefficient for Non-Western*Democracy is negative and significant. That is, Western democracies (including Israel) are more likely to win their wars, but non-Western democracies (excluding Israel) are less likely to win theirs. ${ }^{37}$ We also re-estimated the models excluding Israel's wars $(n=207)$, and the results were consistent, except that the interaction terms were only significant in models that included Capabilities but not Wealth-GDP. Thus, excluding Israel's wars, we still find that Western democracies are more likely to win their wars but nonWestern democracies are less likely to win theirs. Therefore, the results indicate that democratic victory is not universal, but is divisible between Western and non-Western democracies. ${ }^{39}$ In fact, it appears that the democratic victory phenomenon hinges on the classification of a single state, Israel, as Western or non-Western. ${ }^{39}$

Turning to the second contention of the democratic victory thesis, the evidence is clear: Of the three variables of interest, democracy has the weakest impact on the likelihood of victory in war. Lake (2003:166) had argued that "[b]ased on my original results, the probability of victory increases from 0.34 for the most autocratic states to 0.85 for the most democratic, implying that democracies are more than 50 percentage points more likely to win the wars they fight than are autocracies," which is generally consistent with our findings reported above. He adds that " $[\mathrm{t}]$ his is a greater effect than increasing military personnel or iron and steel production from their minimum to maximum values," which is an assertion that democracy has a greater impact than relative capabilities or economic factors. This is similar to his earlier claim that in wars "military strength, industrial capacity, and the ability to choose to wage war appear to be far less important determinants of victory than governmental form" (Lake 1992:32). These latter two claims are not supported by our findings; instead, we find that at their maximum values, Capabilities is associated with a $95 \%$ probability of victory, Wealth-GDP is associated with an $89 \%$ probability of victory, and Democracy is associated with an $81 \%$ probability of victory. These are all impressive effects, but Lake's implication that democracy has a greater effect than either capabilities or wealth is contrary to the evidence.

Reiter and Stam (2003) are more circumspect than Lake in their assertion of the role of democracy in war victory, and it is important to remember that Reiter and Stam's analyses focus mainly on democratic initiators, so one must be careful to separate their effects from those of democracies, in general, especially since initiators are generally more likely to win wars. Nevertheless, they assert that " $[\mathrm{t}]$ he estimates from our data predict that a demo-

\footnotetext{
37 The rate of non-Western democratic victory including Israel's wars is $15 / 18(83 \%)$, which is about the rate of Western democratic victory, 32/37 $(86 \%)$; however, once Israel's wars are moved from the non-West to the West, the success rate of the former is only $8 / 11(73 \%)$ and that of the latter is $39 / 44(89 \%)$. Although excluding Israel's wars, non-Western democracies still win a majority of their wars, the relationship between non-Western democracy and victory is negative once we control for the other variables in our model.

38 Unlike in the case of Democracy, the impact of both Capability and Wealth-GDP is consistent across Western and non-Western regions.

39 Dropping Israel's wars from Reiter and Stam's original model (our Model 1, Table 7), the results are basically unchanged for Democracy*Initiator, but Democracy*Target in Model 4 , Table 7 is not significant. The results are generally consistent using Democracy in Table 8 when these wars are dropped, but Democracy in Model 7, Table 8 is not significant $(p=.11)$. Thus, Reiter and Stam's original findings-which do not control for Western and non-Western democracy-are robust for the exclusion of Israel's wars; however, testing the universality of democratic victory requires such controls, and adding them we find that the democratic victory phenomenon is not universal.
}

cratic initiator (POLITY score of 10 ) has a $93 \%$ chance of winning, whereas a mostly authoritarian regime (POLITY score of -7 ) has only a $62 \%$ of winning, if one appropriately codes all democracy, initiation, and interaction variables and holds other values at their means" (Reiter and Stam 2003:177). When we replicate their analyses, we find that setting Initiation at 1 and Democracy at its highest level, +10 , the probability of victory for democratic initiators is $96 \%$, which although very impressive is still less than the $99 \%$ probability of victory of warring states at their maximum values of Capabilities and the $98 \%$ probability of victory of warring states at their maximum values of Wealth-GDP (when they are initiators). Importantly, Reiter and Stam (2002:197) add that "democracy has also been the surest means to power in the arena of battle", (emphasis added), which seems to be an endorsement of the second contention of the democratic victory thesis, which asserts that democracy-as compared to other factors-is a stronger determinant of victory in interstate war. Our findings gainsay the latter claim and support Desch's claims regarding the greater salience of capabilities in war victory, as well as his argument that wealth plays a greater role in democratic victory than regime type. ${ }^{40}$

Reiter and Stam (2003:176-177) "agree with Desch that material and ideational factors such as industrial capabilities, technology, and military strategy are the critical factors determining [war] outcomes," but they note that "this misses the point" and insist that "democracies are better or more willing to judge the effects of these factors." The latter assertion is plausible and is supported by a finding that democracies are more effective in utilizing relative capabilities and wealth; however, the authors insist that democracies do not win their wars because of their greater capabilities or greater wealth, but that they choose to fight "those wars in which they will enjoy an "unfair fight", (Reiter and Stam 2003:177). But what makes these fights "unfair" is unclear, and it is likely that their "unfairness" derives in part from the asymmetry of relative capabilities and wealth of the democratic and nondemocratic belligerents. Moreover, the claim that "democracies are better or more willing to judge the effects of these factors" takes Reiter and Stam (2002) too far afield of their evidence. For example, if their assertions regarding the ability of democracies to "judge the effects of these factors" is accurate, then it follows that by including these variables in our models as controls-and each of these factors are included as controls in their original models and ours (Tables 8 and 9)-then their inclusion should wash out the impact of the democracy variables in the probit models-which they do not. Similarly, these variables should not have a significant independent impact on war outcomes once we control for democracy in the same equation-but they do. They are left then with something akin to the argument that some domestic factor that is coincidentally more prevalent in the democracies in our sample of wars-but is not precluded from nondemocracies-is the key to democratic victory in war; however, this contention may subsume but possibly contradicts the democratic victory thesis.

\footnotetext{
40 The analyses also allow us to determine whether wealth or democracy has a greater impact on war victory. Given that wealth is significant in each of the three empirical tests, its substantive impact is greater than that of democracy, and democracy is not significantly associated with war duration, we conclude that wealth more than democracy accounts for war victory.
} 


\section{Conclusion}

In this essay, we examined the factors that contribute to victory in interstate war by contrasting three perspectives and utilizing three estimation techniques to assess the empirical accuracy of the rival claims. Findings from cross-tabs reveal that states with greater military capabilities are more likely to win their wars whether they are wealthier or democratic, and democratic states perform marginally better than wealthier states in war. Results of probit analyses revealed that although each of the variables had a consistent, robust, and positive impact on war victory, relative capabilities had the strongest substantive impact on war victory, while wealth had a greater substantive impact on the likelihood of war victory than democracy. Finally, results of hazard rate analyses indicated that states with greater military capabilities fight shorter wars than either democracies or wealthier states, and, controlling for capabilities and wealth, the relationship between democracy and war duration is not significant, which challenges the claim that democracies have a unique propensity to fight shorter wars and are more likely to win their wars as a result. In one of the more important extensions of the debate, we find that the democratic victory phenomenon is not universal, but is contingent on the placement of a single country, Israel, in the Western or non-Western democracy category. Thus, Western democracies (including Israel) are more likely to win their wars, but non-Western democracies (excluding Israel) are less likely to win their wars. The latter finding suggests that future research should examine the impact of regional/cultural or collective identity factors on military victory, but it should also explore the role of unit-level material and nonmaterial factors, ${ }^{41}$ as well as the relationships among wealth, democracy, and military capabilities, which might contribute to the outcomes that we observe. As it stands, our analyses indicate that although each of the three factors contributes to war victory, relative military capability is the most powerful, consistent, and robust predictor of victory in interstate war.

\section{References}

Bayer, Resat, and Michael Bernhard. (2010) The Operationalization of Democracy and the Strength of the Democratic Peace. Conflict Management and Peace Science 27: 85-101.

Bennett, D. Scott, and Allan Stam. (1996) The Duration of Interstate Wars, 1816-1985. American Political Science Review 90: 239-257.

Bennett, D. Scott, and Allan Stam. (1998) The Declining Advantages of Democracy. Journal of Conflict Resolution 42: 344-366.

Bennett, D. Scott, and Allan Stam. (2006) Predicting the Length of the 2003 U.S.-Iraq War. Foreign Policy Analysis 2: 101-115.

Biddle, Stephen, and Stephen Long. (2004) Democracy and Military Effectiveness: A Deeper Look. Journal of Conflict Resolution 48: 525546.

Brooks, RisA. (2003) Making Military Might: Why Do States Fail and Succeed? A Review Essay. International Security 28: 149-191.

Bueno de Mesquita, Bruce, Alastair Smith, Randolph Siverson, and James Morrow. (2004) The Logic of Political Survival. Cambridge, MA: MIT Press.

Calahan, Harold A. (1944) What Makes a War End? New York: Vanguard Press.

Choi, AJin. (2003) The Power of Democratic Cooperation. International Security 28 (1): 142-153.

41 These might include civil military relations, force employment, and nationalism, among others.
Choi, AjIn. (2004) Democratic Synergy and Victory in War, 1816-1992. International Studies Quarterly 48: 663-682.

Coffey, Rosemary. (1965) The Heart of Deterrence. Bulletin of the Atomic Scientists 21: 27-29.

Desch, Michael. (2002) Democracy and Victory: Why Regime Type Hardly Matters. International Security 27: 5-47.

Desch, Michael. (2003) Democracy and Victory: Fair Fights or Food Fights? International Security 28: 180-194.

Desch, Michael. (2008) Power and Military Effectiveness. Baltimore: Johns Hopkins University Press.

Downes, Alexander. (2009a) How Smart and Tough Are Democracies?: Reassessing Theories of Democratic Victory in War. International Security 33 (4): 9-51.

Downes, Alexander. (2009b) Correspondence: Another Skirmish in the Battle over Democracies and War. International Security 34 (2): 200204.

Goldsmith, Benjamin. (2006) A Universal Proposition: Region, Conflict, War and the Robustness of the Kantian Peace. European Journal of International Relations 12: 533-563.

Henderson, Errol. (2009) Disturbing the Peace: African Warfare, Political Inversion, and the Universality of the Democratic Peace Thesis. British Journal of Political Science 39 (1): 25-58.

Henderson, Errol, and Richard Tucker. (2001) Clear and Present Strangers: The Clash of Civilizations and International Conflict. International Studies Quarterly 45: 317-338.

Kecskemeti, Paul. (1958) Strategic Surrender. Stanford, CA: Stanford University Press.

Klingberg, Frank. (1966) Predicting the Termination of War: Battle Casualties and Population Losses. Journal of Conflict Resolution 10: 129-171.

Lake, David. (1992) Powerful Pacifists. American Political Science Review 86: 24-37.

Lake, David. (2003) Fair Fights? Evaluating Theories of Democracy and Victory. International Security 28: 154-167.

Leng, Russell, and Patrick M. Regan. (2003) Social and Political Cultural Effects on the Outcomes of Mediation in Militarized Interstate Disputes. International Studies Quarterly 47 (3): 431-452.

Maddison, Mangus. (2003) The World Economy: Historical Statistics. Paris: OECD Development Centre.

Mearsheimer, John. (1983) Conventional Deterrence. Ithaca, NY: Cornell University Press.

Mearsheimer, John. (2001) The Tragedy of Great Power Politics. New York: WW Norton.

Mousseau, Michael, Havard Hegre, and John Oneal. (2003) How the Wealth of Nations Conditions the Liberal Peace. European Journal of International Relations 9: 277-314.

Organski, A. F. K., and Jacek Kugler. (1978) Davids and Goliaths: Predicting the Outcomes of International Wars. Comparative Political Studies 11: 141-180.

Organski, A. F. K., And Jacek Kugler. (1980) The War Ledger. New Haven, CT: Yale University Press.

Powers, Kathy. (2006) Dispute Initiation and Alliance Obligations in Regional Economic Institutions. Journal of Peace Research 43: 453471.

Reiter, Dan, and Curtis Meek. (1999) Determinants of Military Strategy, 1903-1994: A Quantitative Empirical Test. International Studies Quarterly 43: 363-387.

Reiter, Dan, and Allan Stam. (1998) Democracy, War Initiation, and Victory. American Political Science Review 92: 377-389.

Reiter, Dan, and Allan Stam. (2002) Democracies at War. Princeton, NJ: Princeton University Press.

Reiter, Dan, AND Allan Stam. (2003) Understanding Victory: Why Political Institutions Matter. International Security 28 (2): 168179.

Reiter, Dan, and Allan Stam. (2009) Correspondence: Another Skirmish in the Battle over Democracies and War. International Security 34 (2): 194-200.

Richardson, Lewis. (1960) Statistics of Deadly Quarrels. Pacific Grove, CA: Boxwood Press.

Rosen, Steven. (1972) War, Power, and the Willingness to Suffer. In Peace, War, and Numbers, edited by Bruce Russett. Beverly Hills, CA: Sage.

Sarkees, Meredith Reid, and Frank Wayman. (2010) Resort to War. Washington, DC: CQ Press. 
Singer, J. David, and Melvin Small. (1972) The Wages of War. New York: John Wiley \& Sons.

Singer, J. David, and Melvin Small. (2005) Correlates of War project data. Available at http://correlatesofwar.org/. (Accessed May 7, 2011.)
Stam, Allan. (1996) Win, Lose, or Draw. Ann Arbor: University of Michigan Press.

Wayman, Frank, J. David Singer, and Gary Goertz. (1983) Capabilities, Allocations, and Success in Militarized Disputes and Wars, 1816-1976. International Studies Quarterly 27: 497-515. 